\title{
The Effect of Country Branding Toward E-WoM and Re-visit Intention Through Tourist Satisfaction in Bali (Study on Foreign Tourist in Sari Profit Tour, Bali, Indonesia)
}

\author{
Widhea Citra Dewani* Agus Hermawan Titis Shinta Dhewi \\ State University of Malang, Address: Jalan Semarang 5, Lowokwaru Sub-district, Malang City, East Java, \\ Indonesia
}

\begin{abstract}
One of tourism destinations in Indonesia that is quite attractive to foreign tourists is Bali Island. A tourist, both from Indonesia and abroad is also very influential in tourism promotion. If visitors get a good impression of a tourist destination, it is possible to recommend to friends, relatives, and colleagues to visit the tourist attractions, however if they get a bad impression they might suggest not visiting the place. The increasing of social media users has become an arena to share travel experiences that indirectly have an impact on tourism promotion. This study aimed to understand the effect of country branding toward e-WoM and re-visit intention through tourist satisfaction. The analysis was carried out using Partial Least Square (PLS) with total respondents of 190 foreign tourists. The results of the analysis showed that there was an effect of Country Branding variables against the eWoM and Re-visit Intention through Tourist Satisfaction.
\end{abstract}

Keywords: Country Branding, Wonderful Indonesia, e-WoM, Re-visit Intention, Tourist Satisfaction

DOI: $10.7176 / \mathrm{EJBM} / 11-18-08$

Publication date: June $30^{\text {th }} 2019$

\section{Introduction}

The tourism potential of Indonesia is diverse and very interesting to visit for local and foreign tourists. According to the World Tourism Organization tourism will continue to grow in the period of 2010-2030 whose development direction will be more significant, with the number of foreign tourist arrivals around the world will increase by an average of $3.3 \%$ per year. One of the islands in Indonesia that become favorite destination for foreign tourists is Bali Island. The increment of foreign visit to Bali has been showed by table below.

Table 1.1 Number of Foreign Tourists in Bali During 2010-2017

\begin{tabular}{ccc}
\hline Year & Total Tourist & Growth (\%) \\
\hline 2010 & 2.576 .142 & 8.01 \\
\hline 2011 & 2.826 .709 & 9.73 \\
\hline 2012 & 2.949 .332 & 4.34 \\
\hline 2013 & 3.278 .598 & 11.16 \\
\hline 2014 & 3.766 .638 & 14.89 \\
\hline 2015 & 4.001 .835 & 6.24 \\
\hline 2016 & 4.927 .937 & 23.14 \\
\hline 2017 & 4.697 .739 & 15.62 \\
\hline
\end{tabular}

In order to introduce and develop Indonesia's tourist attraction to the world, the Indonesian government has a slogan titled "Wonderful Indonesia" which in Bahasa interpreted as "Enchantment of Indonesia" which has been used as a tourism country branding since 2011 .

Visiting a tourism spot will have its own impression for the visitors. A good impression that obtained by visitor will foster a sense of satisfaction on tourists on the contrary the bad impression will foster a sense of "surrender" to visit. Zeithaml and Bitner (2000) defined the satisfaction was the response of consumers regarding fulfillment of the needs. The main objective of all business people and service providers is to give satisfaction to customers.

A tourist both from Indonesia and abroad is also very influential against tourism promotion. Nowadays, there are many tourists who document the story of their journey by writing on their personal blogs, uploading travel photos and videos on social media. This is called as e-WoM (electronic Words of Mouth). Humaira and Lili (2016) explained that e-WoM was a digitalization of traditional WOM. WOM is delivered directly from one party to another while submitting e-WoM requires an intermediary media, which is electronic media. Extensive social media coverage can disseminate documentation from blog writers and social media actors about Indonesia throughout the world, thus it can be read by the public.

When a visitor gets a good impression on tourist destination, it encourages the desire of tourists to revisit the tourist destination, even recommending to relatives and colleagues to visit these places. In the study of Khun \& Teng (2011) explained that the interest in revisiting is repurchase intention and behavior that showed willingness to recommend and disseminated positive information to service providers. The intention to re-visit is the same as 
the intention to repurchase.

\section{Methodology and Research}

This research was quantitative research with explanatory research approach. The data analysis used was Partial Least Square using software of Smart PLS. PLS was a structural equation modeling (SEM) based on variance or component to analyze the correlation between one variable based on the assumption that correlation between the variables specified referred to and considered the clear knowledge base where each variable was assumed to represent a theoretical concept represented in the form of latent variables (Ghozali, 2008).

\subsection{Population}

The population in this study was all of foreign tourists who came to Bali, using the services of a tour and travel in "Sari Profit Tour"

\subsection{Sample}

The total of samples was selected using the formula of Daniel \& Terrel, as follows:

Information:

$$
\mathrm{n}=\frac{\mathrm{Z}^{2} \mathrm{pq}}{\mathrm{d}^{2}}
$$

$$
\begin{array}{ll}
\mathrm{n} & =\text { Total of samples } \\
\mathrm{N} & =\text { Total of population } \\
\mathrm{Z} & =\mathrm{Z} \text { value with Alpha } 0.05, \text { thus the value of } \mathrm{Z}=1.96 \\
\mathrm{p} & =\text { Proportion estimation }=0.06 \\
\mathrm{q} & =1-\mathrm{p} \\
\mathrm{d} & =\text { Error Level of Alpha }=0.05
\end{array}
$$

$\mathrm{p}$ value obtained from the following formula:

$$
\mathrm{p}=\frac{N}{n}
$$

According to the calculation of the sample formula above, the total of samples was 173.793984 and rounded up to 174 respondents. Thus, the minimum size of sample was 174, in order to be more representative, the sample was increased by $10 \%$ to 192 respondents.

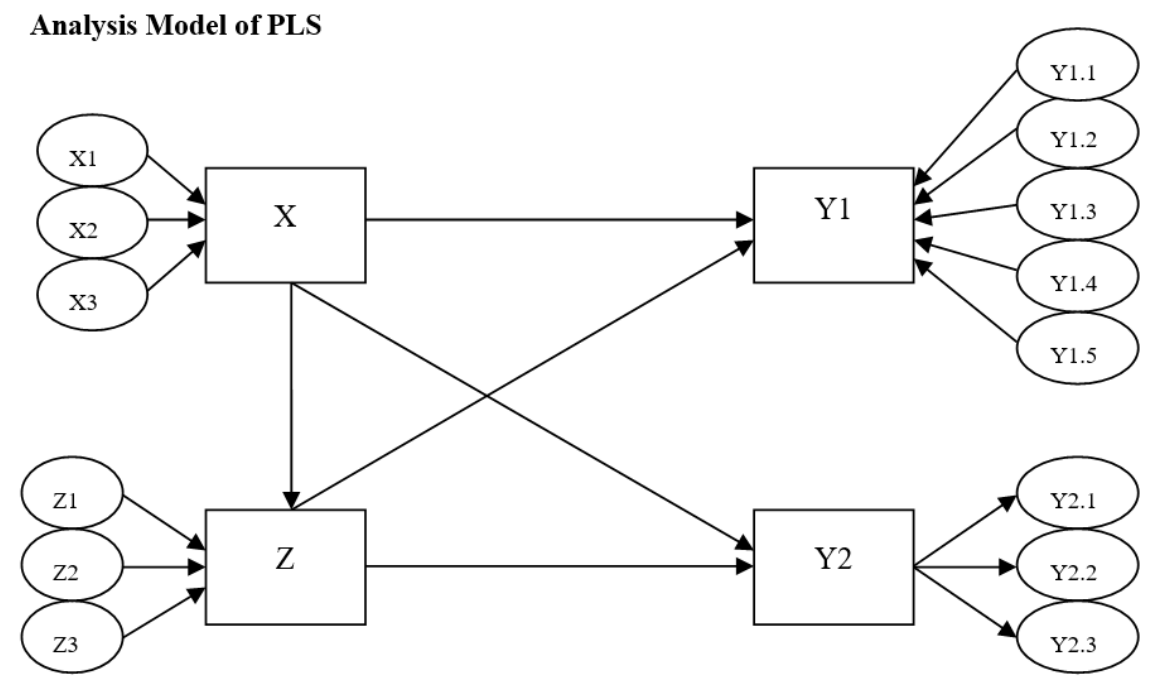

\section{Information:}

$\mathrm{X}$

$\mathrm{X} 1$

$\mathrm{X} 2$

$\mathrm{X} 3$

$\mathrm{Y} 1$

Y1.1

Y1.2

Y1.3

Y1.4

Y1.5
: Country Branding

: Tourism

: Culture

: People

: e-WoM

: Tie strength

: Homophily

: Trust

: Normative Influence

: Informational Influence 


$\begin{array}{ll}\text { Y2 } & : \text { Re-visit Intention } \\ \text { Y2.1 } & \text { : Destination image } \\ \text { Y2.2 } & : \text { Re-visit intention } \\ \text { Y2.3 } & \text { : Recommend to others } \\ \text { Z } & \text { : Tourist Satisfaction } \\ \text { Z1 } & \text { : Feeling happy }\end{array}$

\section{Result and Discussion}

\subsection{Result}

The research was conducted for 2 months on 190 respondents, obtained analysis results as follows:

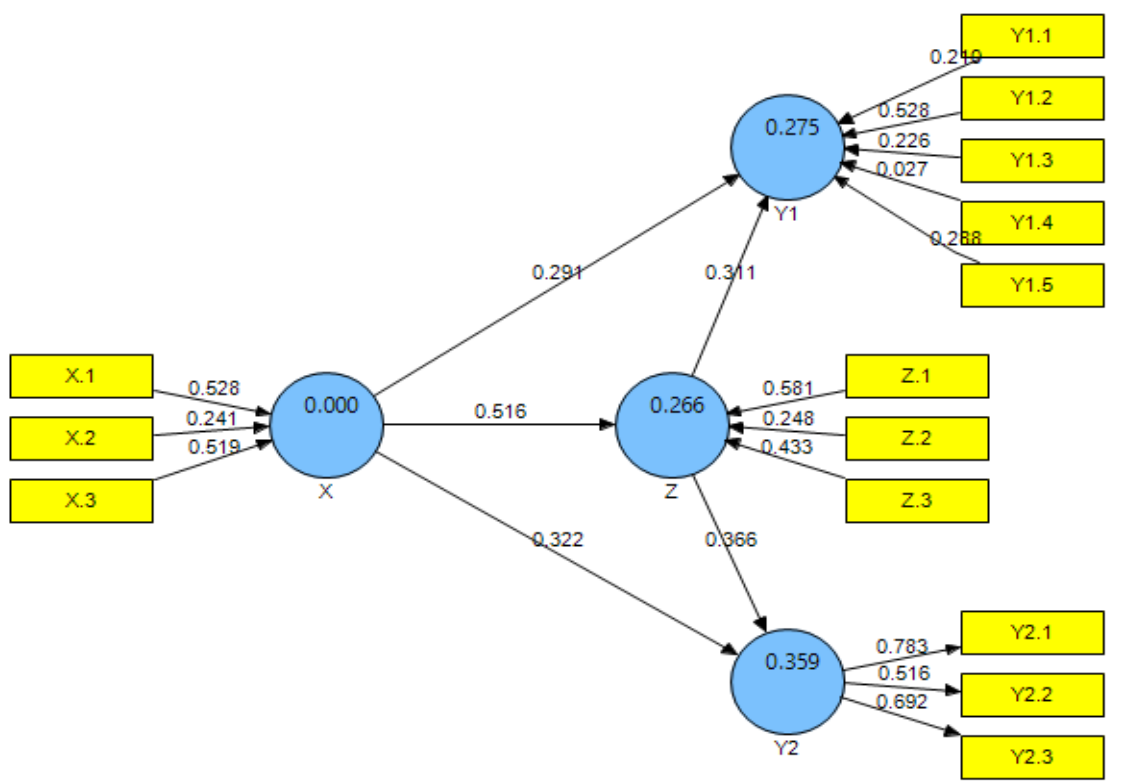

Figure 4.1 Analysis Output of PLS (Step 1)

On step 1 there were invalid indicators on variable of Y1 (e-WoM), which were indicator of Y1.1 (Tie Strength) and Y1.4 (Normative Influence). Thus, step 2 analysis was carried out by eliminating indicators of Y1.1 (Tie Strength) and Y1.4 (Normative Influence) and obtained the following output:

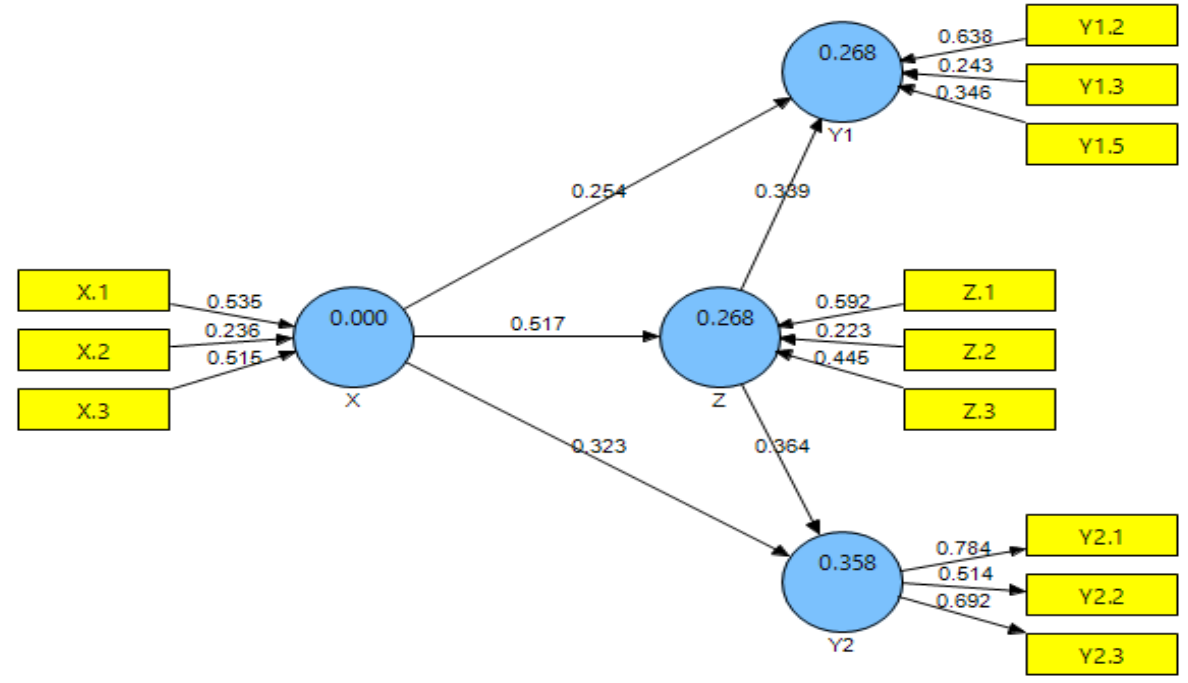

Figure 4.2 Analysis Output of PLS (Step 2) 
Table 4.1 Outer Weights (Mean, STDEV, T-Values)

\begin{tabular}{|c|c|c|c|c|c|c|}
\hline & $\begin{array}{c}\text { Original } \\
\text { Sample } \\
(0)\end{array}$ & $\begin{array}{c}\text { Sample } \\
\text { Mean (M) }\end{array}$ & $\begin{array}{l}\text { Standard } \\
\text { Deviation } \\
\text { (STDEV) }\end{array}$ & $\begin{array}{c}\text { Standard } \\
\text { Error } \\
\text { (STERR) }\end{array}$ & $\begin{array}{c}\text { T Statistics } \\
(\mid \text { O/STERR } \mid)\end{array}$ & P-value \\
\hline X.1 -> X & 0.535 & 0.539 & 0.077 & 0.077 & 6.956 & 0.000 \\
\hline X.2 -> X & 0.236 & 0.229 & 0.083 & 0.083 & 2.830 & 0.005 \\
\hline X.3 -> X & 0.515 & 0.508 & 0.076 & 0.076 & 6.808 & 0.000 \\
\hline Y1.2 -> Y1 & 0.638 & 0.644 & 0.116 & 0.116 & 5.485 & 0.000 \\
\hline Y1.3 -> Y1 & 0.243 & 0.225 & 0.137 & 0.137 & 1.770 & 0.077 \\
\hline Y1.5 -> Y1 & 0.346 & 0.340 & 0.117 & 0.117 & 2.964 & 0.003 \\
\hline Y2.1<- Y2 & 0.633 & 0.632 & 0.052 & 0.052 & 12.056 & 0.000 \\
\hline $\mathrm{Y} 2.2<-\mathrm{Y} 2$ & 0.292 & 0.288 & 0.071 & 0.071 & 4.119 & 0.000 \\
\hline$Y 2.3<-Y 2$ & 0.512 & 0.506 & 0.051 & 0.051 & 9.953 & 0.000 \\
\hline Z.1 -> Z & 0.592 & 0.585 & 0.092 & 0.092 & 6.454 & 0.000 \\
\hline Z.2 -> Z & 0.223 & 0.225 & 0.115 & 0.115 & 1.932 & 0.054 \\
\hline Z.3 -> Z & 0.445 & 0.441 & 0.087 & 0.087 & 5.141 & 0.000 \\
\hline
\end{tabular}

Table 4.2 Direct Effects (Mean, STDEV, T-Values)

\begin{tabular}{ccccccc}
\hline & $\begin{array}{c}\text { Original } \\
\text { Sample (O) }\end{array}$ & $\begin{array}{c}\text { Sample } \\
\text { Mean (M) }\end{array}$ & $\begin{array}{c}\text { Standard } \\
\text { Deviation } \\
\text { (STDEV) }\end{array}$ & $\begin{array}{c}\text { Standard } \\
\text { Error } \\
\text { (STERR) }\end{array}$ & $\begin{array}{c}\text { T Statistics } \\
(\mid \mathbf{O} / \text { STERR|) }\end{array}$ & P-value \\
\hline $\mathbf{X}$-> Y1 & 0.254 & 0.254 & 0.057 & 0.057 & 4.481 & 0.000 \\
\hline $\mathbf{X}$-> Y2 & 0.323 & 0.326 & 0.060 & 0.060 & 5.385 & 0.000 \\
\hline $\mathbf{X}$-> Z & 0.517 & 0.521 & 0.042 & 0.042 & 12.194 & 0.000 \\
\hline $\mathbf{Z}$-> Y1 & 0.339 & 0.345 & 0.062 & 0.062 & 5.432 & 0.000 \\
\hline $\mathbf{Z}$-> Y2 & 0.364 & 0.367 & 0.057 & 0.057 & 6.330 & 0.000 \\
\hline
\end{tabular}

Table 4.3 Indirect Effects (Mean, STDEV, T-Values)

\begin{tabular}{ccccccc}
\hline & $\begin{array}{c}\text { Original } \\
\text { Sample (O) }\end{array}$ & $\begin{array}{c}\text { Sample } \\
\text { Mean (M) }\end{array}$ & $\begin{array}{c}\text { Standard } \\
\text { Deviation } \\
\text { (STDEV) }\end{array}$ & $\begin{array}{c}\text { Standard } \\
\text { Error } \\
\text { (STERR) }\end{array}$ & $\begin{array}{c}\text { T Statistics } \\
(\mid \mathbf{O} / \text { STERR|) }\end{array}$ & P-value \\
\hline X -> Y1 & 0.175 & 0.180 & 0.035 & 0.035 & 4.948 & 0.000 \\
\hline X -> Y2 & 0.188 & 0.191 & 0.034 & 0.034 & 5.603 & 0.000 \\
\hline
\end{tabular}

Table 4.4 Total Effects (Mean, STDEV, T-Values)

\begin{tabular}{ccccccc}
\hline & $\begin{array}{c}\text { Original } \\
\text { Sample (O) }\end{array}$ & $\begin{array}{c}\text { Sample } \\
\text { Mean (M) }\end{array}$ & $\begin{array}{c}\text { Standard } \\
\text { Deviation } \\
\text { (STDEV) }\end{array}$ & $\begin{array}{c}\text { Standard } \\
\text { Error } \\
\text { (STERR) }\end{array}$ & $\begin{array}{c}\text { T Statistics } \\
(\mid \mathbf{O} / \text { STERR|) }\end{array}$ & P-value \\
\hline $\mathbf{X}$-> Y1 & 0.429 & 0.434 & 0.053 & 0.053 & 8.060 & 0.000 \\
\hline $\mathbf{X}$-> Y2 & 0.511 & 0.517 & 0.047 & 0.047 & 10.770 & 0.000 \\
\hline $\mathbf{X}$-> Z & 0.517 & 0.521 & 0.042 & 0.042 & 12.194 & 0.000 \\
\hline $\mathbf{Z}$-> Y1 & 0.339 & 0.345 & 0.062 & 0.062 & 5.432 & 0.000 \\
\hline $\mathbf{Z}$-> Y2 & 0.364 & 0.367 & 0.057 & 0.057 & 6.330 & 0.000 \\
\hline
\end{tabular}

\subsection{Discussion}

Variable of Country Branding against e-WoM showed a $t_{\text {count }}$ of 8.060 ( $\left.>1.96\right)$ which meant that $t_{\text {count }}$ was greater than $\mathrm{t}_{\text {table }}$ thus concluded that $\mathrm{H}_{1}$ was accepted which stated that "Country Branding has an influence on the creation of e-WoM". This hypothesis was supported by the study that conducted by Ching-Fu, et al., which stated that the objective image had a direct and indirect effect on behavioral intentions. In the path of "destination image - tourism - quality - value of satisfaction with behavioral intention" were clearly shown in this study.

Variable of Country Branding against Tourist Satisfaction showed $t_{\text {count }}$ of $12.194(>1.96)$ which meant that 
$\mathrm{t}_{\text {count }}$ was greater than $\mathrm{t}_{\text {table }}$ thus concluded that $\mathrm{H}_{2}$ was accepted. Country Branding influenced Tourist Satisfaction. In the study of Irawan (2017) also mentioned that service quality had an effect on consumer satisfaction and interest in revisiting. Here what was meant by Service Quality was the impression a destination gave to visitors, which meant that customer satisfaction was created because they get a good impression of a product or service.

Variable of Country Branding against Re-visit Intention showed a $t_{\text {count }}$ of $10.770(>1.96)$ which meant that $t_{\text {count }}$ was greater than $t_{\text {table, }}$, thus concluded that $\mathrm{H}_{3}$ was accepted. Country Branding influenced Re-visit Intention. Utami and Gaffar (2014) mentioned that there was influence of nation branding against the visiting decision process of Australian tourists to Indonesia. Thus, could be concluded that the better the tourists' response to Indonesian nation branding, the higher the decision process to visit Indonesia.

Variable of Tourist Satisfaction against Re-visit Intention showed a $t_{\text {count }}$ of $6.330(>1.96)$ which meant that $t_{\text {count }}$ was greater than $t_{\text {table }}$ thus concluded that $\mathrm{H}_{4}$ was accepted. Tourist Satisfaction influenced Re-visit Intention. The study result of Hong-Bumm and Lee (2015) mentioned that there was a positive correlation between the excitement and sophistication of the dynamic personality and city image. Conversely, the correlation between seriousness of personality and negative image was dynamic. The three images of dynamic city: dynamic, specific, and static images showed positive impact on the intention of tourists to revisit the city.

Variable of Tourist Satisfaction against e-WoM showed that $t_{\text {count }}$ was $5.432(>1.96)$ which meant that $t_{\text {count }}$ was greater than $t_{\text {table, }}$, thus concluded that $\mathrm{H}_{5}$ was accepted. Tourist Satisfaction had an influence against e-WoM. The study result of Rodrguez (2016) also said, social media had become a valuable source of tourist experience, where they could explicitly show their qualitative experience and their satisfaction/dissatisfaction with real attributes about a goal

The variables of Country Branding, e-WoM, Re-visit Intention, and Tourist Satisfaction had influence on each other. The hypothesis with the indirect influence of X (Country Branding) against Y1 (e-WoM) through Z (Tourist Satisfaction) had a correlation of 4.948 (>1.96) while in the hypothesis of X (Country Branding) against Y2 (Re-visit Intention) through Z (Tourist Satisfaction) had a correlation of 5.603 (>1.96). It could be concluded that from the two indirect effects on this hypothesis, it was accepted. Country Branding had an influence against e-WoM and Re-visit Intention through Tourist Satisfaction. This hypothesis was also supported by study result of Suzan Coban (2012) that showed the image of a destination influenced positively on satisfaction and satisfaction had a positive influence on loyalty.

\section{Conclusion}

From application of country branding which was being the hallmark of a country to promote tourism potential, then it shown the impression on tourists. When a visitor got a good impression, they would confidently share their experiences with others, from good experience they would feel satisfied and intend to make re-visit. (1) Country Branding of "Wonderful Indonesia" was rated very well by respondents (2) Tourist Satisfaction was felt to be quite satisfied by respondents (3) The involvement of respondents in conducting e-WoM, was very good (4) Respondents' interest in conducting re-visits (Re-visit Intention), was very good.

\section{References}

Anholt, Simon. 2007. Competitive Identity: The New Brand Management for Nations, Cities and Regions. Basingstoke: Palgrave Macmillan

Arikunto, S. 2006. Prosedur Penelitian Suatu Pendekatan Praktik. Jakarta: PT Rineka Cipta

Baker, D. A., \& Crompoton, J. L. 2000. Quality, Satisfaction, and Behavior Intention, Annals of Tourism Research, 27(3)

Basiya, R., \& Rozak, H.A. 2012. Kualitas Daya Tarik Wisatawan, Kepuasan dan Niat Kunjung Kembali Wisatawan Mancanegara di Jawa Tengah. Semarang: Universitas Stikubang

Creswell, J. W. 2014. Research Design: Qualitative, Quantitative and Mixed Methods Approaches. $4^{\text {th }}$ edition. Thousand Oaks, CA: Sage

Coban, Suzan. 2012. The Effect of the Image of Destination on Tourist Satisfaction and Loyalty. European Journal of Social Sciences

Farzin, M., \& Majid, F. 2018. e-WOM through social networking sites and impact on purchase intention and brand image in Iran. Journal of Advances in Management Research

Ghozali, Imam. 2011. Aplikasi Analisis Multivariate Dengan Program SPSS. Semarang: Badan Penerbit Universitas Diponegoro

Hennig-Thurau T., Gwinner K.P., Walsh G., Gremler D.D. (2004). Electronic Word-of Mouth via ConsumerOpinion Platforms: What Motivates Consumers to Articulate Themselves on the Internet?. Journal of Interactive Marketing (1)

Hermawan, Hary. 2017. Pengaruh Daya Tarik Wisatawan, Keselamatan, dan Sarana Wisata Terhadap Kepuasan Serta Dampaknya Terhadap Loyalitas Wisatawan (Studi Community Based Tourism di Gunung Api Purba Nglanggeran). Jurnal Media Wisata, Volume 15, Nomor 1 
Hong-Bumm, Kim Sanggun Lee. 2015. Impacts of City Personality and image on Revisit Intention. Journal of Tourism Cities

Humaira, A., \& Lili, A. 2016. Analisis Faktor Elektronik Word of Mouth (EWOM) dalam Mempengaruhi Keputusan Berkunjung Wisatawan. Tourism and Hospitality Essentials (THE) Journal, Vol. VI, No. 2,2016 $-1049$

Indriani, J., \& Chandra, K. 2017. Pengaruh City Branding Pada City Image dan Keputusan Berkunjung Wisatawan Ke Kabupaten Purwakarta. Jurnal Manajemen Maranatha, Vol. 17, Nomor 1

Irawan, Adi. 2017. Analisis Pengaruh Daya Tarik Wisatawan, Persepsi Harga, dan kualitas Pelayanan Terhadap Minat berkunjung Ulang dengan Kepuasan Konsumen sebagai Variabel Intervening (Studi Pada Objek Wisata Teluk Kiluan). Jurnal Sosial dan Politik

Jalilvand, M. R., Samiei, N., Dini, B., \& Manzari, P. Y. (2012). Examining the structural relationships of electronic word of mouth, destination image, tourist attitude toward destination and travel intention: An integrated approach. Journal of Destination Marketing \& Management

Jannah, B., Zainul A., \& Adriani. 2014. Pengaruh City Branding dan City Image Terhadap Keputusn Berkunjung Wisatawan ke Banyuwangi

Khun-Shan., W., Theng, Y. 2011. Apply the Extend Theory of Planned Behavior to Predict the Intention of Visiting a Green Hotel. African Journal of Business management, Vol. 5 (17)

Kiswanto, Anjar Hari. 2011. Pengaruh Harga, Lokasi dan Fasilitas Terhadap Keputusan Berkunjung Wisatawan di Objek Wisata Dampo Awang Beach Rembang. Jurnal Ekonomi \& Manajemen

Kotler, Amstrong. 2001. Prinsip-Prinsip Pemasaran, Edisi ke duabelas, Jilid 1. Jakarta: Erlangga

Kotler, P., \& Keller, K. L. 2008. Marketing Manajement. Jakarta: Erland

Kotler, P., \& Keller, K. L. 2009. Manajemen Pemasaran, Edisi Ketiga Belas. Jakarta: Erlangga

Lalita, A., \& Ixora L. 2013. Pengaruh Event Terhadap minat Berkunjung Kembali di Margo City (Study Pada Event Holiday on Ice). Jurnal Administrasi Niaga

Maharani Conny P, Rini A., Tomy A. 2014. Pengaruh Brand Positioning Wonderful Indonesia Terhadap Keputusan Wisatawan Mancanegara Untuk berkunjung Ke Indonesia (Survey Terhadap Wisatawan Mancanegara Asal Singapore, Malaysia dan Australia). Jurnal Manajemen Pemasaran Priwisata

Manap H, Abdul. 2016. Revolusi Manajemen Pemasaran. Jakarta: Mitra Wacana Media

Peraturan Kementerian Kebudayaan dan Pariwisata 2011

Prayag, Girish. (2013). Senior Travelers' Motivations And Future Behavioral Intentions: The Case of Nice. Journal of Travel \& Tourism Marketing.

Rachman F, Arief. 2014. Geografi Pariwisata Jawa dan Bali. Jakarta: Penerbit Media Bangsa

Rodrguez, Gonzlez. 2016. Post-Visit and pre-Visit Tourist Destination Image Through eWOM Sentiment Analysis and Perceived Helpfulness. Journal of Travel \& Tourism Marketing

Solimun, Dr. Ir. MS., dkk. 2017. Metode Statistika Multivariat Pemodelan Persamaan Struktural (SEM). Malang: UB Press

Wahab, Salah. Ph.D., 2003. Manajemen Kepariwisataan. Jakarta: Pradnya Paramita

Wang, Chuhan (Renee), \& Marketa, Kubickova. 2014. The Impact of Engaged Users on eWOM of Hotel Facebook Page. Journal of Hospitality and Tourism Technology

Undang-Undang Pariwisata No. 9 tahun 1990

Undang-Undang Republik Indonesia Tahun 2009

Utami, Sri, \& Vanessa, Gaffar. 2014. Pengaruh Strategi Nation Branding “Wonderful Indonesia” Terhadap Proses Keputusan Berkunjung Wisatawan Australia Ke Indonesia. Tourism and Hospitality Essentials (THE) Journal, Vol.IV No.1.2014 - 693

https://id.wikipedia.org/wiki/Badan_Pusat_Statistik (diakses pada 3 Oktober 2018, pukul 19.20)

https://report.weforum.org/travel-and-tourism-competitiveness-index-ranking (diakses pada 7 oktober 2018, pukul 14.22)

https://tourisminframe.wordpress.com/2017/09/12/sejarah-dan-perkembangan-tackline-pariwisata-indonesiahingga-menjadi-wonderful-indonesia/ (diakses pada 14 Oktober 2018, pukul 10.11)

https://www.kemenpar.go.id (diakses pada 5 Oktober 2018, pukul 18.24) 